\title{
The legal consequences of jus cogens and the individuation of norms
}

\author{
Ulf Linderfalk \\ Faculty of Law, Lund University, PB 207, SE-221 00 Lund, Sweden \\ Email: ulf.linderfalk@jur.lu.se
}

\begin{abstract}
International law ascribes to the conferral of a jus cogens status on a norm a particular legal significance. Bluntly put, jus cogens norms have legal consequences that norms of ordinary international law do not. International lawyers have a great many different ideas of what these legal consequences are more precisely. As of yet, the reason for this divide has not been fully clarified. This void tends to confuse jus cogens discourse on several issues such as the immunity of states and state officials in judicial proceedings originating in the violation of $j u s$ cogens norms, or the extradition of alleged perpetrators of international crimes, or again the non-applicability of amnesty laws concerning such crimes. It also impedes the justification of judicial and other legal decisions.

As this article argues, contrary to the general assumption, a lawyer's conception of the legal consequences of jus cogens is not theory-neutral but dependent on his or her preferred understanding of the concept of law. The argument goes briefly as follows: (i) What causes international lawyers to disagree is the issue of whether or not jus cogens norms entail obligations concerned with their own enforcement; (ii) this is essentially an issue concerning the individuation of norms; (iii) depending on whether a lawyer takes the position of a legal positivist or a legal idealist, he or she uses different criteria for the individuation of jus cogens norms; and (iv) this is why, for legal idealists, jus cogens norms entail obligations concerned with their own enforcement, whereas for legal positivists they do not.
\end{abstract}

Keywords: concept of law; individuation of norms; jus cogens; legal consequences; rationality of international legal discourse

\section{Introduction}

Jus cogens is one of the more fundamental of the many concepts applied in international law and international legal discourse. It expresses the idea of the existence of an international lex superior. ${ }^{1}$ The assumption is that jus cogens norms have an authority which exceeds that of ordinary international law. So understood, the concept of jus cogens has had a significant impact on the construction of international legal argument, as the classification of a norm as jus cogens alone will dramatically increase the strength of a legal proposition relying upon that norm. For international legal scholars, who until the introduction of the concept of jus cogens were generally unaccustomed to the idea of the existence of a legal hierarchy among international norms, it has had far-reaching consequences for the construction of the international legal system.

As experience shows, the idea of jus cogens does not easily translate into practical action. ${ }^{2}$ Like all concepts applied in international law and legal discourse, jus cogens serves as an intermediate

\footnotetext{
${ }^{1}$ Compare Draft Conclusion 2 of the ILC Special Rapporteur, Mr Dire Tladi: 'Norms of jus cogens ... are hierarchically superior to other norms of international law' (UN Doc A/71/10, 299).

${ }^{2}$ See, e.g., J. d'Aspremont, 'Jus Cogens as a Social Construct Without Pedigree', (2015) 46 Netherlands Yearbook of International Law 85-114.

(C) Foundation of the Leiden Journal of International Law 2020. This is an Open Access article, distributed under the terms of the Creative Commons Attribution-NonCommercial-NoDerivatives licence (http://creativecommons.org/licenses/by-nc-nd/4.0/), which permits noncommercial re-use, distribution, and reproduction in any medium, provided the original work is unaltered and is properly cited. The written permission of Cambridge University Press must be obtained for commercial re-use or in order to create a derivative work.
} 
link in inferences from identifying criteria to legal consequences. ${ }^{3}$ Identifying criteria are the particular properties used in international law for the classification of an international norm as one that comes within the scope of the jus cogens concept. Legal consequences is the particular significance ascribed in international law to having so categorized an international norm. What makes the jus cogens concept problematic is the huge divide that exists between different lawyers' understanding of both of these two categories of elements. ${ }^{4}$ Lawyers' descriptions of the identifying criteria of jus cogens vary greatly from person to person and are often mutually exclusive. To give some examples, suggestions have been made that in international law, jus cogens norms shall be identified based on: their fundamental character; the importance of the values that they represent; the interest or interests that they satisfy, or the entity or group of entities in which those interests are vested; the legal relationship or relationships that they establish; their origin or the source of law from which they derive; their deontic character; or the legal consequences ensuing from their classification as jus cogens. ${ }^{5}$ Lawyers' descriptions of the legal consequences of jus cogens range from the most narrow of interpretations of Articles 53 and 64 of the 1969 Vienna Convention on the Law of Treaties, ${ }^{6}$ to suggestions imposing upon states and international organizations some very far-reaching positive obligations concerned with the enforcement jus cogens norms, such as any of the below:

- States have a duty to exercise jurisdiction over offences prohibited by peremptory norms of international law (jus cogens), when committed by their nationals or on a territory under their jurisdiction. ${ }^{7}$

- The principle of equality and non-discrimination has entered the realm of jus cogens, and consequently, '[s]tates are obliged ... to eliminate regulations of a discriminatory nature, to combat practices of this nature, and to establish norms and other measures that recognize and ensure the effective equality before the law of each individual'. ${ }^{\circ}$

- Because aggression, war crimes, and crimes against humanity are prohibited in jus cogens terms, if a head of state has committed such crimes, other states have an obligation to assassinate that person. ${ }^{9}$

Scholars are left to speculate over the precise reason or reasons for this doctrinal divide. To the extent of the disagreement over identifying criteria, the relevant explanation would seem to lie in lawyers' different understandings of the concept of international law. There is an inextricable

\footnotetext{
${ }^{3}$ Compare A. Ross, 'Tû-tû', (1956-1957) 70 Harvard Law Review 812-25.

${ }^{4}$ See U. Linderfalk, Understanding Jus Cogens in International Law and International Legal Discourse (2020), 34-8.

${ }^{5}$ See, in turn, Commentaries appended by the ILC to the 2001 Draft Articles on Responsibility of States for Internationally Wrongful Acts, Report of the work of the $53^{\text {rd }}$ session of the ILC, UN Doc A/56/10, 111; First report on jus cogens by Dire Tladi, Special Rapporteur, UN Doc A/CN.4/693, 38; Commentaries appended by the ILC to the 2001 Draft Articles on Responsibility of States for Internationally Wrongful Acts, Report of the ILC of the work of its $53^{\text {rd }}$ session, UN Doc A/56/10, 113; Conclusions of the work of the Study Group on the Fragmentation of International Law: Difficulties arising from the Diversification and Expansion of International Law, Report of the work of the $58^{\text {th }}$ session of the ILC, UN Doc A/61/10, 183; W. Czapliński, 'Concepts of jus cogens and Obligations erga omnes in International Law in the Light of Recent Developments', (1997/98) 23 Polish Yearbook of International Law 87, at 88; J. Vidmar, 'Rethinking Jus Cogens After Germany v. Italy: Back to Article 53?', (2013) 60 Netherlands International Law Review 1, at 17; J. Brunnée, 'The Prohibition on Torture: Driving Home?', (2010) 104 Proceedings of the American Society of International Law 454, at 457.

${ }^{6}$ See, e.g., J. Frowein, 'Ius Cogens', (2012) 6 Max Planck Encyclopedia of Public International Law 443, at 445.

${ }^{7}$ Third report on peremptory norms of general international law (jus cogens) by Dire Tladi, Special Rapporteur, UN Doc A/CN.4/714 and Corr 1, 68 .

${ }^{8}$ YATAMA v. Nicaragua, Inter-American Court of Human Rights, Preliminary objections, Merits, Reparations and costs, Ser C No 127, Judgment of 23 June 2005, para. 185.

${ }^{9}$ L. R. Beres, 'Prosecuting Iraqi Crimes against Israel during the Gulf War: Jerusalem's Rights under International Law', (1992) 9 Arizona Journal of International and Comparative Law 337, at 351-8.
} 
relationship between a lawyer's idea of the source of the jus cogens status of norms and his or her understanding of the criteria, which identify an international norm as having precisely this status. ${ }^{10}$ If you maintain, for example, that the jus cogens status of norms derive from customary international law-making processes, ${ }^{11}$ by logical necessity, you will have to contend that the identification of jus cogens norms be done through observations of the general practice of states and manifestations of their opinio juris. Similarly, if you insist that the jus cogens status of norms derives from the commitment of participants in international legal discourse to some or other overarching ideal, such as justice, legality or the accommodation of the common basic goods of all human beings, ${ }^{12}$ you will have to take an approach to the identification of a jus cogens norms stressing their efficacy. As you will have to contend, a norm is jus cogens, if the legal consequences tied to this status are necessary to realize the presupposed legal ideal. ${ }^{13}$

To the extent of the disagreement over the legal consequences of jus cogens, scholars have typically appealed to other explanatory reasons. As most would seem to believe, the legal consequences of jus cogens are theory-neutral, or at least not similarly dependent on any particular understanding of the concept of law. ${ }^{14}$ It is the objective of this article to refute all such assumptions. Thus, this article will argue that a lawyer's understanding of the concept of international law bears directly upon his or her understanding of the legal consequences of jus cogens, just as it bears directly on his/her understanding of identifying criteria.

The argument will be laid out step-by-step, in five consecutive sections. Section 2 will identify the predominant point of divergence among international lawyers' different understandings of the legal consequences of jus cogens. As the section will establish, what causes disagreement is the issue of whether or not jus cogens norms entail obligations concerned with their own enforcement. Section 3 will identify this divide as essentially an issue concerning the individuation of norms. As the section will establish, if lawyers disagree over the issue of whether or not jus cogens norms entail obligations concerned with their own enforcement, this is because they have different ideas of the criteria, which allow them to conceive of an international norm as one norm, distinct from all others. Sections 4-5 will identify the criteria used by international lawyers for the individuation of jus cogens norms. As these sections will establish, depending on your preferred understanding of the concept of international law, you will use criteria that help you understand norms, either as separate units in a logical system, or as means for the realization of assumed legal ideals. Section 6 will provide the critical explanation of the relationship between the use of different criteria of individuation and different understandings of the legal consequences of jus cogens. This section will establish that, depending on your preferred understanding of the concept of international law, jus cogens norms either entail or do not entail obligations concerned with their own enforcement. Section 7 will conclude the article by adopting a meta-perspective. It will share a few thoughts on why it is important that participants in international legal discourse fully acknowledge the relationship between submitted jus cogens propositions and preferred understandings of the concept of international law.

\section{The point of divergence}

When legal scholars give a description of the legal consequences of jus cogens, they typically refer to the definition laid down in Article 53 of the 1969 Vienna Conventions on the Law of Treaties

\footnotetext{
${ }^{10}$ See Linderfalk, supra note 4 , at $112-13$.

${ }^{11}$ See, e.g., Czapliński, supra note 5 , at 88 .

${ }^{12}$ See, in turn, A. Orakhelashvili, 'Natural Law and Justice', (2007) 7 Max Planck Encyclopedia of Public International Law at 523-35; E. Suy, 'The Concept of Jus Cogens in International Law', Papers and Proceedings of the Conference held in Lagonissi, Greece, 3-8 April 1966, 17, at 27; D. Dubois, 'The Authority of Peremptory Norms in International Law: State Consent or Natural Law?', (2009) 78 Nordic Journal of International Law, at 159-60.

${ }^{13}$ See, e.g., U. Linderfalk, 'Understanding the Jus Cogens Debate: The Pervasive Influence of Legal Positivism and Legal Idealism', (2015) 46 Netherlands Yearbook of International Law 51, at 68-9.

${ }^{14}$ See, e.g., D. Costelloe, Legal Consequences of Peremptory Norms in International Law (2017), passim.
} 
(VCLT). ${ }^{15}$ What this practice would seem to assume is that Article 53 serves as an accurate description of the legal consequences of jus cogens, not only for the somewhat limited purposes of the Vienna Convention, but also beyond. The Article reads:

For the purposes of the present Convention, a peremptory norm of general international law is a norm accepted and recognized by the international community of States as a whole as a norm from which no derogation is permitted and which can be modified only by a subsequent norm of general international law having the same character. ${ }^{16}$

As Article 53 makes apparent, the legal consequences of jus cogens fall into three separate categories. First, the conferral of a jus cogens status on a norm brings with it a series of new obligations. For example, a norm may impose on states an obligation to abstain from perpetrating acts of torture. ${ }^{17}$ Elevating this norm to a jus cogens status entails the creation of new obligations such as the priority-rule implicitly confirmed by the International Court of Justice in the Jurisdictional Immunities of the State case: in the event of a conflict between a jus cogens norm and a rule of customary international law, states must act upon the former. ${ }^{18}$ It may be appropriate to establish a terminology that helps distinguish between these two categories of obligations - on the one hand obligations such as the prohibition of torture, and on the other hand obligations such as those ensuing from the elevation of this prohibition to a jus cogens status. This is why they will be referred to in this article as 'primary' and 'secondary jus cogens obligations', respectively.

Second, the conferral of a jus cogens status on a norm has an effect on the law-making powers of states and international organizations. According to the definition of jus cogens laid down in Article 53 of the VCLT, if a jus cogens status is conferred on a norm, henceforth, this norm can be modified only by the creation of a subsequent norm having the same character. This proposition translates into a no-competence rule: if a jus cogens status has been conferred on a norm, then states and international organizations have no power to modify this norm except by the creation of a new norm having the same character. In this article, legal consequences of this category will be referred to as 'secondary jus cogens no-competences'.

Third, if the conferral of a jus cogens status on a norm has an effect on the powers of states and international organizations qua lawmakers, then it has also a corresponding effect on their legal obligations qua legal decision-makers. If states or international organizations take action to modify a jus cogens norm, although they have been incapacitated by law to do so, the question arises: What will now be the effect of this action for their legal obligations? If 'power' is defined as the capacity to change or create a legal relationship, it would seem reasonable to think that, absent

\footnotetext{
${ }^{15}$ See, e.g., J. Allain, 'The jus cogens Nature of non-refoulement', (2001) 13 International Journal of Refugee Law 533, at 534; S. T. Helmersen, 'The Prohibition of the Use of Force as Jus Cogens: Explaining Apparent Derogations', (2014) 61 Netherlands International Law Review 167, at 170; D. S. Mitchell, 'The Prohibition of Rape in International Humanitarian Law as a Norm of Jus Cogens: Clarifying the Doctrine', (2005) 15 Duke Journal of Comparative \& International Law 219, at 228; A. Orakhelashvili, 'The Impact of Peremptory Norms on the Interpretation and Application of United Nations Security Council Resolutions', (2005) 16 European Journal of International Law 59, at 63; J. Vidmar, supra note 5, at 3.

${ }^{16} 1155$ UNTS 331.

${ }^{17}$ The jus cogens status of the prohibition of torture has been affirmed by several authorities, including the International Court of Justice, the International Criminal Tribunal for Former Yugoslavia, and the Inter-American Court of Human Rights. See, in turn, Questions relating to the Obligation to Prosecute or Extradite (Belgium v. Senegal), Judgment of 20 July 2012 , ICJ Rep. 2012, 422, at para. 99; Prosecutor v. Furundžija, Case No IT-95-17/1-T, Trial Chamber, Judgement of 10 December 1998 , available at: www.icty.org/x/cases/furundzija/tjug/en/fur-tj981210e.pdf, para. 155; Servellon García v. Honduras, Merits, Reparations and costs, Ser C No 152, Judgment of 21 September 2006, available at: www.corteidh.or.cr/docs/casos/ articulos/seriec_152_ing.pdf, para. 97.

${ }^{18}$ Jurisdictional Immunities of the State (Germany v. Italy; Greece intervening), Judgment of 3 February 2012, ICJ Rep. 2012, 99, at para. 92 .
} 
such a power, no legal effect can ensue from the action. The relevant rules of the Vienna Convention provide accordingly. As laid down in Articles 53 and $64,{ }^{19}$ respectively:

- If, at the time of its conclusion, a treaty is in conflict with a jus cogens norm, that treaty is void ...

- If a new jus cogens norm emerges, then any existing treaty in conflict with that norm becomes void and terminates.

The fact that a treaty is void implies, by definition, the negation of the legal state of affairs that its conclusion would have brought otherwise. If what is brought by the conclusion of a treaty is a series of new obligations, consequently, for any situation in which a norm $(\mathrm{N})$ is in conflict with a treaty, it would seem fitting to say that the conferral of a jus cogens status on $\mathrm{N}$ also brings with it a series of 'secondary jus cogens no-obligations'. In the case of Articles 53 and 64, these noobligations would be phrased as follows:

1. If, at the time of its conclusion, a treaty is in conflict with a jus cogens norm, then no party to this treaty must perform it.

2. If a new jus cogens norm emerges, and this norm is in conflict with an already existing treaty, then no party to this treaty must perform it.

Similar no-obligations are claimed outside of the context of the 1969 Vienna Convention. Obvious examples are Articles 53 and 64 of the 1986 Vienna Convention on the Law of Treaties, ${ }^{20}$ which have a wording identical to those of Articles 53 and 64 of the 1969 Vienna Convention, except that a treaty is concluded between states and international organizations or between international organizations inter se.

Even more interesting among the many claims made by international lawyers are the secondary jus cogens obligations, no-competences and no-obligations that concern action other than the conclusion of a treaty. Examples include:

3. If a state or an international organization makes a reservation to a treaty, and this reservation purports to modify a jus cogens norm, then parties to the treaty must not act upon this reservation. ${ }^{21}$

4. If an international organization takes a decision, which purports to modify a jus cogens norm, then members of the organization must not act upon this decision. ${ }^{22}$

5. If a state makes a unilateral declaration, which purports to modify a jus cogens norm, then no state must act upon that declaration. ${ }^{23}$

6. In the event of a conflict between a jus cogens norm and a rule of customary international law, states must act upon the former. ${ }^{24}$

\footnotetext{
${ }^{19}$ It should be noted that, according to Art. 44 of the VCLT, no separation of single clauses of a treaty is permitted.

${ }^{20}$ Vienna Convention on the Law of Treaties between States and International Organizations or between International Organizations, adopted on 21 March 1986, UN Doc. A/CONF.129/15. At the time of writing, however, this Convention has not yet entered into force.

${ }^{21}$ See, e.g., Art. 4.4.3(2) of the Guide to Practice on Reservations to Treaties, Report of the ILC on the work of its $63^{\text {rd }}$ session, UN Doc A/66/10, at 35 .

${ }^{22}$ See, e.g., Draft Conclusion 17, Third report on peremptory norms of general international law (jus cogens), supra note 7 , at 67 .

${ }^{23}$ See, e.g., Guiding Principles applicable to unilateral declarations of States capable of creating legal obligations, Report of the ILC on the work of its $58^{\text {th }}$ session, UN Doc A/61/10, at 161 .

${ }^{24}$ See, e.g., Jurisdictional Immunities of the State, supra note 18, para. 92.
} 
7. States have a duty to exercise jurisdiction over offences prohibited by peremptory norms of international law (jus cogens), whenever these are committed by their nationals or on a territory under their jurisdiction. ${ }^{25}$

8. Because a jus cogens status is conferred on the prohibition of torture, states must not refuse extradition of a perpetrator of torture under any political offence exemption. ${ }^{26}$

9. Because aggression, war crimes, and crimes against humanity are prohibited in jus cogens terms, if a head of state has committed such crimes, other states have a right to abduct that person for the purposes of prosecution; similarly, they have an obligation to assassinate him or her. ${ }^{27}$

10. Because the prohibition of genocide is jus cogens, when a reservation is made to Article IX of the Genocide Convention, exempting the jurisdiction conferred on the International Court of Justice under this provision, then that reservation is null and void. ${ }^{28}$

11. 'Immunity of ratione materiae shall not apply to any offence prohibited by a peremptory norm of general international law (jus cogens)'. ${ }^{29}$

12. 'The fact that an offence prohibited by a peremptory norm of general international law (jus cogens) was committed by a person holding an official position shall not constitute a ground excluding criminal responsibility'. ${ }^{30}$

13. The principle of equality and non-discrimination has entered the realm of jus cogens, and consequently, '[s]tates are obliged not to introduce discriminatory regulations into their laws, to eliminate regulations of a discriminatory nature, to combat practices of this nature, and to establish norms and other measures that recognize and ensure the effective equality before the law of each individual'. ${ }^{31}$

14. Statutes of limitation do not apply to any crimes, which are prohibited by a jus cogens norm. $^{32}$

This list helps to identify the point of the divergence of opinion that exists among international lawyers' different understandings of the legal consequences of jus cogens. The suggested examples of existing secondary jus cogens obligations, no-competences and no-obligations fall into two distinct conceptual categories. Whereas the first six examples bear on the performance of primary jus cogens obligations, examples 7 through 14 bear in various ways on the enforcement of these same obligations. Not all lawyers are prepared to accept that there should be anything in international law corresponding to suggestions of the latter of the two categories. Many find these suggestions anomalous, far removed from any sound understanding of the jus cogens concept. ${ }^{33}$ This observation raises an important question of legal theory: Why is it that some international lawyers find it peculiar that the jus cogens status of norms should have a bearing on the enforcement of primary jus cogens obligations, whereas other international lawyers obviously do not? Answering this question is the task set for Sections 3-6 of this article. As will gradually transpire, much of the answer

\footnotetext{
${ }^{25}$ Third report on peremptory norms of general international law, supra note 7 , at 68 .

${ }^{26}$ See, e.g., Prosecutor v. Furundžija, supra note 17, paras. 155-7.

${ }^{27}$ See, e.g., Beres, supra note 9, at 351-8.

${ }^{28}$ This was one of the arguments invoked by the DRC in Armed Activities on the Territory of the Congo to establish the jurisdiction of the International Court of Justice. See Armed Activities on the Territory of the Congo (New Application: 2002) (Democratic Republic of Congo v. Rwanda), Jurisdiction and Admissibility, Judgment of 3 February 2006, ICJ Rep. 2006, 6, at para. 56.

${ }^{29}$ Third report on peremptory norms of general international law, supra note 7 , at 68 .

${ }^{30}$ Ibid.

${ }^{31}$ YATAMA v. Nicaragua, supra note 8, 185.

${ }^{32}$ See, e.g., Almonacid-Arellano v. Chile, Preliminary objections, Merits, Reparations and costs, Ser C No 154, Judgment of 26 September 2006, available at: www.corteidh.or.cr/docs/casos/articulos/seriec_152_ing.pdf, para. 153.

${ }^{33}$ See, e.g., D. Costelloe, supra note 14, at 51; H. Thirlway, The Sources of International Law (2014), at 145; R. Kolb, Peremptory International Law - Jus Cogens (2015), at 108-12; S. Talmon, 'Jus Cogens after Germany v. Italy: Substantive and Procedural Rules Distinguished', (2012) 25 Leiden Journal of International Law 979-1002.
} 
turns on the conditions for the performance of secondary jus cogens obligations, no-competences and no-obligations.

\section{Why the individuation of jus cogens norms is at all an issue}

A basic condition for the performance of secondary jus cogens obligations, no-competences and noobligations is the existence of a conflict of two norms. More precisely, the performance of secondary jus cogens obligations, no-competences and no-obligations presupposes in all cases the existence of a conflict between a jus cogens norm and a norm of ordinary international law. This condition is easily recognized in the case of suggested secondary jus cogens obligation No. 6. It is equally so in the case of each of the suggested jus cogens no-obligations Nos. 1 through 5, all of which refer to action that purports to modify a jus cogens norm. 'Modification' in this case means the creation of a new norm of ordinary international law, which, if valid, would have served as a reason for legal decision-makers to depart from an existing jus cogens norm, wholly or partly. ${ }^{34}$

Contrary to what may possibly be a first impression, the existence of a conflict of norms is assumed also in the case of other suggested secondary jus cogens obligations, no-competences and no-obligations. If suggested secondary jus cogens obligation No. 7 causes controversy, it is precisely because, according other rules of international law, states have only a right to exercise jurisdiction over jus cogens offences committed by their nationals or on a territory under their jurisdiction. ${ }^{35}$ Similarly, suggested secondary jus cogens obligation No. 9 causes controversy because, according to other rules of international law, state-sponsored foreign assassination is prohibited. $^{36}$ Suggested secondary jus cogens no-obligation No. 10 causes controversy because, according to other rules of international law, a reservation to a treaty shall be valid unless: it is not prohibited by a treaty; or the treaty provides that only specified reservations, which do not include the reservation, may be made; or the reservation is incompatible with the object and purpose of the treaty. ${ }^{37}$ And so forth.

By posing the requirement of the existence of a normative conflict, secondary jus cogens obligations, no-competences and no-obligations raise two questions:

1. In the context of secondary jus cogens obligations, no-competences and no-obligations, what are the conditions for referring to a situation as a conflict between a jus cogens norm and a norm of ordinary international law?

2. What are the criteria that allow international lawyers to conceive of a jus cogens norm as one norm, distinct from all other norms of international law?

International lawyers respond differently to Question 1. This divergence of opinion can be explained by the different preferred understandings of lawyers of the concept of international law. Based on the way in which international lawyers have traditionally approached issues concerning the source of jus cogens norms, most would seem to fit the description of either a legal positivist or a legal idealist. For a legal positivist, a jus cogens rule is in conflict with a rule of ordinary international law when: (i) both rules are binding on a legal subject at some particular point in time or during some particular time period; and (ii) both rules are applicable relative to some particular conduct or state of affairs; and (iii) depending on which of the two rules is applied, this conduct or state of affairs will be either consistent or inconsistent with international law. ${ }^{38}$ For a legal idealist, a jus cogens rule is in conflict with a rule of ordinary international law when: (i) both

\footnotetext{
${ }^{34}$ Compare Art. 41 of the VCLT.

${ }^{35}$ See, e.g., V. Lowe and C. Staker, 'Jurisdiction', in M. Evans (ed.), International Law (2010), 313, at 320-5.

${ }^{36}$ See, e.g., the principle of non-intervention, as reflected in the Friendly Relations Declaration, UNGA res. 2525.

${ }^{37}$ Compare Art. 19 of the VCLT.

${ }^{38}$ See Linderfalk, supra note 4 , at $154-74$.
} 
norms are binding on some particular legal subject at some particular point in time or during some particular time period; and (ii) both norms are applicable relative to some certain concrete conduct or state of affairs; and (iii) the effect of the application of the one norm would be contrary to the teleological principle underlying the other, or inconsistent with a commitment to the ideal that this rules is assumed to serve. ${ }^{39}$ This observation sheds some light on the overall extremely perplexing jus cogens discourse. However, it does not help to explain why, according to some lawyers, jus cogens norms entail obligations concerned with their own enforcement, whereas, according to others, they do not. As this article will argue, the critical explanation of this precise divergence of opinion lies rather in the different understandings of legal positivists and legal idealists of the proper criteria for the individuation of norms.

A legal norm is an abstract element in the lawyer's description of a legal system. This entity may be inscribed on a piece of paper or uttered orally, such as in a treaty provision, in a passage of a judicial decision, in an official statement made by an organ or a representative of a state or an international organization, in an amicus brief submitted by an NGO, or in a paper presented by a scholar at an academic conference. Importantly, it is analytically separate from its verbal manifestations. Consider, for example, Article 218, paragraph 1 of the United Nations Convention on the Law of the Sea:

When a vessel is voluntarily within a port or at an off-shore terminal of a State, that State may undertake investigations and, where the evidence so warrants, institute proceedings in respect of any discharge from that vessel outside the internal waters, territorial sea or exclusive economic zone of that State in violation of applicable international rules and standards established through the competent international organization or general diplomatic conference. ${ }^{40}$

While this provision certainly provides some information about an international norm, obviously, it does not give this norm full expression. It presupposes the definitions of the three concepts of 'internal waters', 'territorial sea', and 'exclusive economic zone', which are given elsewhere in the Convention. ${ }^{41}$ It similarly presupposes the contents of 'rules and standards' that are obviously established by other instruments. This plain example proves the point, since without the existence of norms in the abstract, lawyers would not be able to reach this conclusion. It is with the concept of a legal norm as with a sentence in the linguist's description of a language system: if a distinction had not been made between a sentence and the instances of its use, people would not be able to say that a series of words is incomplete or incorrectly combined.

The concept of a legal norm raises two questions of fundamental importance for legal theory. First, there is the question concerning the way in which legal norms should be individuated: Which are the criteria that allow international lawyers to conceive of international norms as separate from other norms of the international legal system? Second, there is the question concerning the way in which single norms should be seen to form part of the international legal system: How do individual norms relate to other individual norms, and how do they interact with other possible elements of the international legal system? These questions are interrelated. As legal philosophers have convincingly demonstrated, whatever criteria a lawyer uses for the individuation of legal norms, these will inevitably be dependent on his or her understanding of the legal system to which these norms belong. ${ }^{42}$ This conclusion applies to international law as much as to any domestic legal system.

Two schools of thought dominate the way international lawyers and scholars talk and write about jus cogens norms. They will be referred to throughout this article as 'legal positivism'

\footnotetext{
${ }^{39}$ Ibid.

${ }^{40} 1833$ UNTS 397.

${ }^{41}$ For a definition of the concepts of internal waters and territorial sea, see Part II, Section 1. For a definition of the exclusive economic zone, see Art. 55.

${ }^{42}$ See J. Raz, The Concept of a Legal System (1980), at 80-92; J. Penner, The Idea of Property in Law (1997), at 38.
} 
and 'legal idealism', respectively. ${ }^{43}$ Sections $4-5$ will identify the criteria used by these two schools of thought for the individuation of jus cogens norms.

\section{The individuation of jus cogens norms according to legal positivism}

Legal positivism ties the existence of legal norms to their pedigree and source of origin. ${ }^{44}$ In international law, put more precisely, a norm exists because its authority can be traced back to one or several other international norms, and ultimately to a source of law recognized by the basic criteria of the legal system - that is to say, to an international agreement, to customary international law, to 'the general principles of law recognized by civilized nations', or to a unilateral declaration. Part and parcel of this understanding of the concept of law is a theory of the concept of a legal order and its constituent elements. ${ }^{45}$ For legal positivism, legal norms are the sole element of a legal system. These norms are organized according chains of authority - according to the way in which they confer authority on one another. For legal positivism, while there is nothing outside of these chains of authority that can be included in the concept of law, the relationship between norms cannot be anything other than their relationship qua norms. That is to say that in a positivist's system of thought, international law is structured according to principles of deontic logic.

This position inevitably comes with a particular idea of the criteria that are to be used for the individuation of norms. Individual norms relate to other individual norms as separate units in a logical system. Hence, for legal positivism, the criteria that enable international lawyers to separate norms from one another are those that help to understand them as precisely such units. To enable a more detailed account of these criteria, as below, a distinction will have to be made among legal norms, depending on whether they are regulative or constitutive in character.

Constitutive norms introduce new abstract classifications of already existing 'brute' facts - in the terminology of legal philosophy, they bring new 'institutional facts' into being. ${ }^{46}$ These norms lay down the conditions for the existence of a legal entity or phenomenon, such as a state, an investor or a valid treaty; they determine the meaning of legal terms, such as 'human rights', 'high seas', or 'the wrongful act of a state'; they confer powers on entities such as courts and international organizations, thereby giving them the ability to bring yet other institutional facts into being, such as judgments, agreements and budgetary decisions. A constitutive norm is complete if and only if it provides, first, an abstract classification (such as the concept of a state, the meaning of the 'high seas', or a certain power conferred upon a court), and second, a complete list of all the conditions for referring a brute fact under this classification. ${ }^{47}$ To illustrate, consider Articles 2 and 13 of the Articles on Responsibility of States for Internationally Wrongful Acts:

\footnotetext{
${ }^{43}$ Legal positivism is understood throughout in the sense of exclusive legal positivism. No attention will be paid to inclusive legal positivism, which takes a markedly more flexible stance to questions concerning the moral constraints on the concept of law. As a result, it is very likely that not all international lawyers, who think of themselves as legal positivists, will feel at home with the description of the legal positivist's preferred understanding of the concept of law given in this article. These lawyers would have to recall the objective of the article, which in no way pretends to provide a description of the actual universes of thought or mind-sets of any single international lawyers. As indicated in Section 1, the article aims to explain the divide between different international lawyers' respective understanding of the legal consequences of jus cogens. Identifying legal positivism with the 'harder' of its several different versions would seem to be justified, while it helps to throw this divide into sharper relief.

${ }^{44}$ See, e.g., L. Green, 'Legal Positivism', in E. N. Zalta (ed.), The Stanford Encyclopedia of Philosophy (2009), available at plato.stanford.edu/archives/fall2009/entries/legal-positivism.

${ }^{45}$ Raz, supra note 42 , at $121-208$.

${ }^{46}$ See, e.g., N. MacCormick and O. Weinberger, An Institutional Theory of Law: New Approaches to Legal Positivism (1986), at 9.

${ }^{47}$ See, e.g., A. Peczenik, On Law and Reason (1989), at 277-81.
} 


\section{Article 2}

There is an internationally wrongful act of a State when conduct consisting of an action or omission: (a) is attributable to the State under international law; and (b) constitutes a breach of an international obligation of the State ...

\section{Article 13}

An act of a State does not constitute a breach of an international obligation unless the State is bound by the obligation in question at the time the act occurs. ${ }^{48}$

These Articles do not express two separate norms. What they put into words are different elements of a single constitutive norm, which provides the conditions for classifying an act as internationally wrongful.

Regulative norms are norms of conduct. They prescribe, prohibit or permit conduct or states of affairs, such as assistance to the United Nations, interference with the exercise of any freedom of the high seas, or forcible action taken by a member state of the United Nations. A regulative norm is complete if and only if it provides, first, a description of the specific kind of conduct or state of affairs being prescribed, prohibited, or permitted (as the case may be), and secondly, each and every single condition, of which the prescription, prohibition, or permission is dependent. ${ }^{49}$ In this sense, Article 109, paragraph 4 of the United Nations Convention on the Law of the Sea does not provide a complete legal norm:

On the high seas, a State having jurisdiction in accordance with paragraph 3 may, in conformity with article 110, arrest any person or ship engaged in unauthorized broadcasting and seize the broadcasting apparatus.

Other elements of this norm are provided in Article 109, paragraph 3, and Article 110, as well as Article 86 and Article 109, paragraph 2, which define what is to be understood by 'the high seas' and by 'unauthorized broadcasting', respectively.

\section{The individuation of jus cogens norms according to legal idealism}

What distinguishes the legal idealists' understanding of the concept of law from that of legal positivists is their entirely different attitude towards the relationship between law and social order. Whereas legal positivism sees law as a form of social order valuable in its own right, legal idealism does not. ${ }^{50}$ For legal idealism, no law can be self-justifying. If law exists, then this is because of the presence of some or other idea, either of what law should be like, or what the legal project should achieve. ${ }^{51}$ To have an idea of what law should be like, or what law should achieve, is to set an ideal for the legal project. ${ }^{52}$ Although legal idealists are divided over the issue of what it is precisely that international law aspires to do, they all have this fundamental idea in common: compliance with an international norm is never a goal in itself; the only goal that eventually counts is the realization of the presumed legal ideal.

\footnotetext{
${ }^{48}$ As restated in the annex to UNGA res. $56 / 83$.

${ }^{49}$ See, e.g., Peczenik, supra note 47 , at 276.

${ }^{50}$ See, e.g., S. Coyle, 'Positivism, Idealism and the Rule of Law', (2006) 26 Oxford Journal of Legal Studies 257-88. 'Legal idealism' is a shorthand term used by legal philosophers to refer to a great variety of different theories about the concept of law. They range from Christian naturalism and social contract theory to the work of twentieth century international scholars and theorists such as George Scelle, Alfred Verdross, John Finnis, Lon Fuller, and Ronald Dworkin. For further reading on this topic see Linderfalk, supra note 4, at 53-9.

${ }^{51}$ Ibid.

${ }^{52}$ On the concept of an ideal see S. Taekema, The Concept of Ideals in Legal Theory (2010), at 1-45.
} 
When a jus cogens status is conferred on a norm, for legal idealists, this is because there is no other way that the presumed legal ideal can be realized. ${ }^{53}$ This position comes with a particular idea of the proper criteria for the individuation of jus cogens norms. In the conceptual universe of legal idealism, individual jus cogens norms relate to other individual norms as means for the realization of an assumed legal ideal. The criteria that enable international lawyers to separate individual jus cogens norms from other norms of international law are those that help to understand them as precisely such means.

To clarify this proposition, consider the right of self-determination of peoples. This right has been referred to by the International Law Commission and other authorities as a clear-cut example of a jus cogens norm. ${ }^{54}$ Its further implications have been set forth by the UN General Assembly in several paragraphs of the annex of Resolution 2625 (XXV), often referred to as 'the Friendly Relations Declaration'. ${ }^{55}$ Some of these are included in the quote below:

1. By virtue of the principle of equal rights and self-determination of peoples enshrined in the Charter of the United Nations, all peoples have the right freely to determine, without external interference, their political status and to pursue their economic, social and cultural development, and every State has the duty to respect this right in accordance with the provisions of the Charter.

2. Every State has the duty to ... render assistance to the United Nations in carrying out the responsibilities entrusted to it by the Charter regarding the implementation of the principle of equal rights and self-determination of peoples ...

5. Every State has the duty to refrain from any forcible action which deprives peoples referred to above in the elaboration of the present principle of their right to self-determination and freedom and independence. In their actions against, and resistance to, such forcible action in pursuit of the exercise of their right to self-determination, such peoples are entitled to seek ... support in accordance with the purposes and principles of the Charter.

As legal positivism would describe these paragraphs, they express a series of different regulative norms. These norms impose a series of different duties on different legal subjects. Paragraph 1 imposes a duty on all those members of the United Nations, which have assumed responsibilities for the administration of territories, and whose peoples have not yet attained a full measure of selfgovernment. These members are required to take action to ensure the realization of the right of self-determination. Paragraph 2 imposes a duty on all states; these are required to render assistance to the United Nations. The first sentence of paragraph 5 imposes on all states the duty to abstain from taking such forcible action, which deprives a people of its right of self-determination. The second sentence of paragraph 5 imposes on all states the duty to acknowledge the right of peoples to seek support in their resistance to forcible action.

Legal idealists would describe the three paragraphs differently. For them, the conferral of a jus cogens status on the right of self-determination is a means for the realization of some or other legal ideal. For the sake of the argument, say that this ideal is the accommodation of the common basic needs of human beings - although, of course, many legal idealists would not agree with this suggestion, but would insist that some other ideal or ideals are at stake. To justify this view, legal idealists would refer to the legal consequences of this conferral represented by the many secondary jus cogens obligations, no-competences and no-obligations attached to the right of

\footnotetext{
${ }^{53}$ See Linderfalk, supra note 4 , at $86-92$.

${ }^{54}$ See, e.g., the Commentaries appended by the ILC to the 2001 Draft Articles on Responsibility of States for Internationally Wrongful Acts, Report of the work of the $53^{\text {rd }}$ session of the ILC, UN Doc. A/56/10, at 85.

${ }^{55}$ Declaration on Principles of International Law concerning Friendly Relations and Co-operation among States in accordance with the Charter of the United Nations, adopted on 24 October 1970.
} 
self-determination. Having these obligations, no-competences and no-obligations will prevent derogations from the right of self-determination; it will preclude modifications of this same right unless accomplished by the creation of new jus cogens norms. Crucially, what will help to ensure realization of the presupposed legal ideal - in this example, the accommodation of the common basic needs of human beings - is not the absence of derogations and modifications of the right of self-determination. The conferral of a jus cogens status on the right of self-determination is a means for the accommodation of the common basic needs of human beings because giving this status to the right helps to eradicate external interference with the way in which peoples determine their political status and pursue their economic, social and cultural development.

This is the criterion of individuation that legal idealists would apply for their analysis of the Friendly Relations Declaration. As they would understand the resolution, paragraphs 1, 2, and 5 provide elements of one single norm. The duty of some members of the United Nations to take action to ensure the realization of the right of self-determination; the duty of all states to render assistance to the United Nations; the duty of all states to refrain from forcible action, which deprives a people of its rights of self-determination; and the duty of all states to acknowledge the right of peoples to seek support in their resistance to forcible action - these duties all serve as means for the accommodation of the common basic needs of human beings in the exact same way. More precisely, they help to eradicate external interference with the way in which peoples determine their political status and pursue their economic, social and cultural development.

\section{The enforcement of jus cogens norms}

Knowing the different criteria used by legal positivists and legal idealists for the individuation of jus cogens norms will help to answer the principal question of this article: Why is it that some international lawyers find it peculiar that the jus cogens status of norms should have a bearing on the enforcement of primary jus cogens obligations, whereas other international lawyers obviously do not? To facilitate the further analysis of this issue, it seems apt to give it some concretion. This concretion can be obtained by drawing on the facts of the Jurisdictional Immunities of the State case. ${ }^{56}$

In brief, this is the relevant background. Italy had allowed tort claims to be brought against Germany in Italian courts based on violations of international humanitarian law committed by German armed forces and other organs of the German Reich during its occupation of Italy in 1943-1945. Violations in many cases involved the commission of war crimes and crimes against humanity: the large-scale killing of civilians as part of a policy of reprisals; deportation of members of the civilian population to slave labour in Germany; and the denial of prisoner of war status to members of the Italian armed forces, who were similarly used as forced labourers. Certainly, Germany had itself taken several steps to ensure the reparation of victims of Nazi persecution during the Second World War. However, it had excluded from the scope of its national compensation schemes most claims by Italian military internees on the ground that prisoners of war were not entitled to compensation for forced labour. ${ }^{57}$

In its application, Germany asked the Court to adjudge and declare that Italy, by allowing Italian citizens to bring tort claims against Germany in Italian courts, had failed to respect the jurisdictional immunity of that state under customary international law, and by so doing had engaged its international responsibility. As Italy maintained, Germany was not entitled to immunity because its acts involved the violations of jus cogens rules. ${ }^{58}$ In considering this argument, the Court noted that it assumed the existence of a conflict between the rule of state immunity and the

\footnotetext{
${ }^{56}$ Jurisdictional Immunities of the State, supra note 18.

${ }^{57}$ Ibid., paras. $20-6$.

${ }^{58}$ Ibid., para. 92 .
} 
rules of international law which prohibit the perpetration of war crimes and crimes against humanity. In the opinion of the Court, no such conflict existed:

The two sets of rules address different matters. The rules of State immunity are procedural in character and are confined to determining whether or not the courts of one State may exercise jurisdiction in respect of another State. They do not bear upon the question whether or not the conduct in respect of the proceedings are brought was lawful or unlawful. ${ }^{59}$

There can be little objection to this finding. The prohibitions of war crimes and crimes against humanity are oft-cited examples of international jus cogens norms. ${ }^{60}$ However, they are not, in the case at hand, applicable relative to the same concrete conduct as the rule of state immunity. This is a first obvious condition for categorizing the situation as a conflict of norms, however this concept is defined. Italy had forestalled this pronouncement. In its Counter-Memorial, it had argued that in the determination of whether or not a conflict existed, focus should be less on the violations of humanitarian law committed by the German Reich, and more on the duty of Germany to redress those violations. ${ }^{61}$ As Italy insisted, Germany had not only a jus cogens duty to abstain from the perpetration of war crimes and crimes against humanity, but also a jus cogens duty to make reparations for any such crimes when committed. Italy had a corresponding jus cogens duty not to absolve Germany of any liability incurred in respect of war crimes and crimes against humanity. ${ }^{62}$ The International Court was not convinced. As it pronounced:

The duty to make reparation is a rule which exists independently of those rules which concern the means by which it is to be effected. The law of State immunity concerns only the latter; a decision that a foreign State is immune no more conflicts with the duty to make reparation than it does with the rule prohibiting the original wrongful act. Moreover, against the background of a century of practice in which almost every peace treaty or post-war settlement has involved either a decision not to require the payment of reparations or the use of lump-sum settlements and set-offs, it is difficult to see that international law contains a rule requiring the payment of full compensation to each and every individual victim as a rule accepted by the international community of States as a whole as one from which no derogation is permitted. ${ }^{63}$

This particular passage is central to any researcher's analysis of the legal consequences of jus cogens and the individuation of jus cogens norms. Obviously, the Court was thinking of the duty of Germany to abstain from perpetrating war crimes as derived from a different norm than the duty of Italy not to absolve Germany of any liability incurred in respect of any such crimes. In so doing, as will now be explained, it took a distinctly positivist approach to the issue of the individuation of jus cogens norms.

For legal positivism, the criteria that enable international lawyers to separate norms from one another are those that help to understand them as separate units in a logical system. If, according to some international norm, Germany is prohibited from perpetrating war crimes, admittedly, it does not necessarily follow that this prohibition applies unconditionally - that it is stated in such terms that it can be regarded as logically self-sufficient. The application of the prohibition of war crimes may be dependent on certain conditions, just as, for example, the application of the

\footnotetext{
${ }^{59}$ Ibid., para. 93.

${ }^{60}$ See, e.g., Fourth report on peremptory norms of general international law (jus cogens), by Dire Tladi, Special Rapporteur, prepared for the seventy-first session of the International Law Commission, 29 April-7 June and 8 July-9 August 2019, UN Doc. A/CN.4/727, at 38 and 52.

${ }^{61}$ Jurisdictional Immunities of the State (Germany v. Italy; Greece intervening), Counter-Memorial of Italy, 22 December 2009, available at www.icj-cij.org/files/case-related/143/16648.pdf, paras 5.7-5.26.

${ }^{62}$ Ibid.

${ }^{63}$ Jurisdictional Immunities of the State, supra note 18, para. 94.
} 
prohibition of the use of force, which is conditional upon the fact that force is not being resorted to by a state in the exercise of its inherent right of self-defence. The point is that if ever there is a general duty of states not to absolve other states of any liability incurred in respect of any war crime, from the point of view of legal positivism, this duty does not in any way modulate the prohibition of war crimes. The different duties are concerned with two entirely separate categories of conduct. It is for this reason that legal positivists will not regard them as elements of one single norm. Naturally, the duty of states not to absolve other states of any liability incurred in respect of any war crime may result from a norm which itself has the status of jus cogens - but this issue must be dealt with separately. The point is that just because states have a jus cogens obligation not to perpetrate war crimes, for legal positivists, they will not ipso facto also have a jus cogens duty not to absolve other states of any liability incurred in respect of any such crimes.

This same reasoning helps to explain the profound doubt that many international lawyers experience when confronted with suggested secondary jus cogens obligations, no-competences and noobligations like those, which were earlier numbered as 7 through $14 .{ }^{64}$ These are all concerned with the enforcement of primary jus cogens obligations, just like the alleged duty of Italy not to absolve Germany of any liability incurred in respect of any war crimes or crimes against humanity. Unlike suggested secondary jus cogens obligations, no-competences and no-obligations Nos. 1-6, they do not address the same category of conduct as the primary jus cogens obligation. In the case of suggested secondary jus cogens obligation No. 8, for example, torture is an entirely different matter than the extradition of alleged perpetrators of such crimes. This is why legal positivists will refuse to accept any claim suggesting the existence of secondary jus cogens obligations, no-competences and noobligations such as Nos. 7-14. As legal positivists understand things, no obligations concerning the enforcement of a primary jus cogens obligation can derive from the same international norm as the primary jus cogens obligation itself. For legal positivists, any claim suggesting the existence of a secondary jus cogens obligation such as No. 8 requires a justification separate from that of the primary jus cogens obligation. This is to say that it presupposes the existence of a separate international norm.

A great number of international lawyers and scholars have commented upon the Jurisdictional Immunities of the State case.$^{65}$ Many of them find the reasoning of the Court unconvincing. ${ }^{66}$ Like Italy, they prefer to conceive of the situation as one involving two norms, each of which concerns the enforcement of international obligations. According to the one norm, Italy has an obligation not to exercise jurisdiction over any tort claims brought against Germany in Italian courts. According to the other, Italy has a duty not to absolve Germany of any liability incurred in respect of war crimes and crimes against humanity. This is precisely the position that a legal idealist would logically take. Considered as means for the realization of whatever ideal is being presumed, the duty of Germany to abstain from perpetrating war crimes cannot be distinguished from the duty of Italy not to absolve Germany of any liability incurred in respect of such crimes. Both duties serve to eradicate the perpetration of war crimes. From the point of view of legal idealism, they derive for this reason from the same international norm.

\footnotetext{
${ }^{64}$ See supra note 33.

${ }^{65}$ See, e.g., A. Bianchi, 'Gazing at the Crystal Ball (again): State Immunity and Jus Cogens beyond Germany v Italy', (2013) 4 Journal of International Dispute Settlement 1-19; F. Boudreault, 'Identifying Conflicts of Norms: The ICJ Approach in the Case of the Jurisdictional Immunities of the State (Germany v. Italy: Greece Intervening)', (2012) 25 Leiden Journal of International Law 1003-12; D. Costelloe, supra note 14, at 267-73; C. Espósito, 'Jus Cogens and Jurisdictional Immunities of States at the International Court of Justice: A Conflict Does Exist', (2011) 21 Italian Yearbook of International Law 161-74; U. Linderfalk, 'The Principle of Rational Decision-Making: As Applied to the Identification of Normative Conflicts in International Law', (2013) 73 Zeitschrift für ausländisches öffentliches Recht und Völkerrecht 591-614; A. Orakhelashvili, 'The Classification of International Legal Rules: A Reply to Stefan Talmon', (2013) 26 Leiden Journal of International Law 89-103; S. Talmon, supra note 33; J. Vidmar, supra note 5; T. Weatherall, 'Jus Cogens and Sovereign Immunity: Reconciling Divergence in Contemporary Jurisprudence', (2014/2015) 46 Georgetown Journal of International Law 1151-212.

${ }^{66}$ See, e.g., C. Espósito, supra note 65, at 161-74; A. Orakhelashvili, supra note 65, at 89-103.
} 
This same analysis explains the attitude of legal idealists to questions concerning the enforcement of primary jus cogens obligations generally. For a legal idealist, primary jus cogens obligations and secondary jus cogens obligations, no-competences and no-obligations are in all cases functionally indistinguishable. What applies in the particular case of the duty of Italy not to absolve Germany of any liability incurred in respect of war crimes applies in the case of all secondary jus cogens obligations, no-competences and no-obligations. Reference can be made, once again, to suggested secondary jus cogens obligation No. 8. If ever there is an obligation of a state to extradite alleged perpetrators of torture, this obligation has the same function as the prohibition of torture itself: the eradication of torture. Because of this functional identity, legal idealists conceive of primary and secondary jus cogens obligations, no-competences and no-obligations as derived in all cases from the same international norm. It is on this point that legal positivists and legal idealists disagree. In critically examining suggested secondary jus cogens obligation No. 8, for example, legal positivists would say that it presupposes the existence of two norms: the one imposes an obligation to abstain from the perpetration of torture; the other imposes an obligation to extradite alleged perpetrators of torture. For legal idealists, there is only one norm, doing all the same thing at the same time.

\section{Conclusions}

Despite an abundance of scholarly work and a steadily expanding jurisprudence, international legal discourse is still struggling to come to grips with the jus cogens concept. Admittedly, legal discourse has helped to clarify the significance of Article 53 of the 1969 Vienna Convention on the Law of Treaties. International lawyers now take for granted that this Article reflects the existence in international law of a general rule, which serves to define the concept of jus cogens generally, and not only for the strictly limited purposes of the Convention itself. This concurrence of opinion, however, exists only on the most superficial of levels. As aptly illustrated by the issue of the legal consequences of jus cogens, when one looks for an adequate answer to the many concrete questions that are bound to be raised in the course of the application of the general rule, very little agreement remains.

International scholars have reason to ruminate over the precise reason or reasons for this lack of agreement - much like this article did in an attempt to explain the divide between lawyers' different understanding of the legal consequences of jus cogens. Potentially, legal discourse is a powerful institution. By sharing legal propositions in verbal form, international lawyers are able to obtain knowledge about international law that they would not be able to obtain without this communicative enterprise. The way in which the jus cogens discourse has come to develop, now, it is certainly not comparable to just any part of international legal discourse. When international lawyers enter discussions of the identifying criteria and legal consequences tied to the jus cogens concept, they do that with a very strong adversarial attitude: they are unprepared and unwilling to question and reassess their respective position; in many cases they refuse to acknowledge that alternative positions even exist. In observing this state of the art, some scholars would seem to have lost faith in the potential of jus cogens discourse entirely, and to have drawn the conclusion that we do best in starting to regard what is being said and written on this topic as little more than wishful thinking. ${ }^{67}$ This article would like to suggest something different. As it insists, jus cogens discourse has the potential to increase our knowledge of international law, just like any other part of international legal discourse. We just have to do something to improve conditions for communication. The way to achieve this improvement is to clarify some basic assumptions that discussants bring to bear on their respective analyses and consideration of the international jus cogens regime.

\footnotetext{
${ }^{67}$ See, e.g., M. Koskenniemi, 'International Law in Europe: Between Tradition and Renewal', (2005) 16 European Journal of International Law 113, at 122.
} 
In this precise spirit, this article asked a very precise question: Why is it that some international lawyers find it peculiar that the jus cogens status of norms should have a bearing on the enforcement of primary jus cogens obligations, whereas other international lawyers obviously do not? As the article established, the answer to this question eventually turns on international lawyers' different understandings of the concept of international law. According to the position necessarily taken by a legal idealist, jus cogens norms entail obligations concerned with the enforcement of primary jus cogens obligations. According to the position taken by a legal positivist, primary and secondary jus cogens obligations are imposed by two entirely separate sets of norms.

As it appears, in the consideration of jus cogens issues, there is no way in which lawyers can remain theory-neutral. A lawyer's understanding of the concept of international law bears directly upon his or her understanding of the legal consequences of jus cogens, just as it bears directly on his/her understanding of identifying criteria. This observation should work to increase the output of the jus cogens discourse. Knowing the relationship between submitted propositions and a legal positivist's or legal idealist's frame of mind will help international lawyers and scholars to relinquish their hitherto adversarial approach to jus cogens issues. Adversarial debate breaks issues down into two opposing positions, of which one is right and one is wrong. If the divide between lawyers' different understandings of the identifying criteria and legal consequences of jus cogens eventually turns on whether lawyers are approaching issues with a legal positivist's or a legal idealist's frame of mind, then the question of who is right and who is wrong will no more be the obvious focus of the debate. The two modes of understanding jus cogens issues will both be right, in the particular universe of thought that they assume. What will remain of the adversarial debate is just the question of whether, in their respective universe of thought, lawyers are consistent or not.

The more interesting question that lawyers should start to engage with is whether, in the particular context of jus cogens discourse, the legal positivist's and the legal idealist's respective conceptions of jus cogens can coexist. As this article would like to suggest, they certainly can. Indeed, the article would like to take the argument one step further: in a rational jus cogens debate, the existence of both positions is necessary to ensure its success. The article will conclude by sharing three preliminary thoughts on why this argument should be accepted:

In a legal universe where discussants are fully aware of the dependence of their respective positions on a legal positivist's or a legal idealist's conception of jus cogens, the coexistence of these two conceptions will contribute to a fuller understanding of the many issues of legal practice that are ultimately at stake.

As this article made apparent, the legal positivist's and legal idealist's respective understanding of the legal consequences of jus cogens will in many cases be mutually exclusive. To illustrate this point, reference can be made to the suggested secondary jus cogens obligations, no-competences and no-obligations numbered from 7 to 14 . At the current stage of development of the practice and opinio juris of states, legal positivists would find many of these suggestions difficult to accept; legal idealists would find them more attractive. From the point of view of a construction of international law, this is to say that the two conceptions of jus cogens will often be in conflict. As long as we conceive of international law as a coherent system of thought, hence, they cannot both be endorsed, but will compete for approval. In international legal discourse, however, there is nothing inherently problematic about a conflict between the legal positivist's and the legal idealist's respective jus cogens conception. On the contrary, a conflict of legal conceptions tends to draw attention to the underlying structural issues. In a legal universe where discussants are fully aware of the dependence of their respective positions on a legal positivist's or a legal idealist's conception of jus cogens, this will lead to a more penetrating legal analysis and fuller exploration of the topic. ${ }^{68}$

${ }^{68}$ Compare V. Jeutner, Irresolvable Norm Conflicts in International Law: The Concept of a Legal Dilemma (2017), at 148-53. 
In a legal universe where discussants are fully aware of the dependence of their respective positions on a legal positivist's or a legal idealist's conception of jus cogens, the coexistence of these two conceptions will work to enhance the legitimacy of the international jus cogens regime.

As several scholars have demonstrated, legal discourse contributes to the formation and development of international norms. ${ }^{69}$ The legitimacy of these norms is dependent on the rationality of this same discourse, which is ensured through participants' application of a series of norms. ${ }^{70}$ Fundamentally, according to one of these norms, every participant should be free to challenge every claim made by every other participant. This is to say that every uttered proposition is contestable, and no debate on any issue should ever be seen as having reached completion. Instead, legal discourse should allow at all times the introduction of new arguments, as long as these are supported by reasons. Jus cogens makes the application of this norm more difficult, and severely limits the possibility of challenging legal claims. In a legal universe where discussants are fully aware of the dependence of their respective positions on a legal positivist's or a legal idealist's conception of jus cogens, the coexistence of these two conceptions works in the opposite direction. It serves to liberate discussants. Thus, it sustains the rationality of international legal discourse and enhances the legitimacy of the international jus cogens regime.

In a legal universe where discussants are fully aware of the dependence of their respective positions on a legal positivist's or a legal idealist's conception of jus cogens, the coexistence of these two conceptions will serve to facilitate the evaluation of international law and legal discourse.

To sustain the rationality of international legal discourse, it is important that legal utterances be fully understood and all their necessary premises evaluated. This objective calls for what Julie Dickson has referred to as an 'attitude of due wariness..$^{71}$ Jus cogens arguments do many things apart from merely describing the identifying criteria of jus cogens norms and their several legal consequences. They are means for social interaction, uttered to affect the beliefs, attitudes and behaviours of potential addressees, that is to say, the potential readers and listeners of legal utterances. What enables jus cogens arguments to have this effect is the social meaning of the term jus cogens. Importantly, the meaning of jus cogens helps utterers to convince addresses of the correctness of their arguments; it helps addressees to process arguments independently of any lawmakers' understanding of ' $j u s$ cogens'; it helps utterers to camouflage the true nature of their argument and to make addressees falsely believe that utterers are able to provide a fairly good description of the lex lata; it helps utterers to inflate the importance of statements that on closer scrutiny might be rather trivial; just as it helps utterers to prevent addressees from questioning their intents. ${ }^{72}$ To enable evaluation of jus cogens arguments, it is important that these social meanings of the term be fully understood. In a legal universe where discussants are fully aware of the dependence of their respective positions on a legal positivist's or a legal idealist's conception of jus cogens, the coexistence of these two conceptions help to ensure that, each in their own way.

\footnotetext{
${ }^{69}$ On this topic see, e.g., U. Linderfalk, 'The Functionality of Conceptual Terms in International Law and International Legal Discourse', (2013) 6 European Journal of Legal Studies at 27-50; J. D’Aspremont, 'Wording in International Law', (2012) 25 Leiden Journal of International Law at 575-602; I. Venzke, How Interpretation Makes International Law (2012), passim.

${ }^{70}$ On this topic see, e.g., R. Alexy, A Theory of Legal Argumentation (1989), passim.

${ }^{71}$ J. Dickson, 'Ours is a Broad Church: Indirect Evaluative Legal Philosophy as a Facet of Jurisprudential Analysis', (2015) 6 Jurisprudence at $227-8$.

${ }^{72}$ Further on the social meaning of jus cogens, see U. Linderfalk, 'All the Things that You Can Do With Jus Cogens: A Pragmatic Approach to Legal Language’, (2013) 56 German Yearbook of International Law at 351-83.
} 